\title{
The metabolism of aged seeds. The ribonucleolytic activity of rye grain embryos of different ages
}

\author{
KAZIMIERZ ZALEWSKI
}

The Chair of Plant Physiology and Biochemistry, Agricultural-Technical Academy, 10-957 Olsztyn-Kortowo. Poland

(Received: June 20. 1985. Accepted: September 26. 1985)

\begin{abstract}
Winter rye grain, harvested in various years and exhibiting clearly differing viability, was studied. Higher total ribonucleolytic activity was found in the post-ribosomal supernatant than in the ribosomes themselves. The ribonucleolytic activity of cytoplasmic ribosomes declined as the germination ability of the rye grain decreased. A similar relationship was observed in the post-ribosomal supernatant. Two additional, in comparison with fully viable grain, ribosome-associated RNase activities $(\mathrm{pH} 5.0$ and 8.3 ) were found in the grain with the lowest $(2 \%)$ viability.
\end{abstract}

Key words: ribosomes, ribonuclease, aging, seeds

\section{INTRODUCTION}

The importance and physiological roles of intracellular nucleolytic enzymes in plants are relatively poorly understood. It is supposed that, aside from degradation of nucleic acids, RNases also take part in RNA synthesis (Barker and Douglas 1960, Gołaszewski 1964, Hsia o 1968) and DNases in DNA synthesis (Sierakowska 1969). The view has also been presented that there are two RNase fractions: one synthesizing and one exclusively degrading RNA (Kulka 1971). A role played by RNases in the regulation of protein synthesis has also not been excluded. RNases play an important role in the transport of RNA, transforming highly polymerized RNA into low molecular weight degradation products appropriate for translocation during seed germination (Kulka 1971).

Proteins having RNase properties have been found in plastids (Gołaszewski 1964, Szarkowski 1965), mitochondria (Rytel et al. 1968 Kulka. 
1969) and ribosomes (Hsia o 1968). The highest total activity is, however. characteristic of the supernatant obtained after pelleting cell nuclei and mitochondria (Gołaszewski 1964, Szarkowski 1965). Because only a small amount of RNase is linked with ribosomes (Hsiao 1968), the main activity of this enzyme is connected with its soluble form found in the cytoplasm of embryo cells.

Siwecka et al. (1979) have shown that the optimum $\mathrm{pH}$ for the RNase linked with the ribosomes of rye embryos is 7.8. Three additional, high RNase activities were also observed at $\mathrm{pH} 4.5,5.2$ and 6.4. Most of the RNases are released from ribosomes when the latter are dissociated into subunits. This fact has lead many researchers to state that the ribonucleolytic activity of ribosomes is a result of adsorption of RNases by them (Tal and Elson 1963, Szafrański et al. 1964, Siwecka et al. 1979).

No studies to date have been done on the relationship between the process of seed aging and the ribonucleolytic activity of ribosomes. For this reason, the purpose of this study was to discover the relationship between the loss of viability of rye grain during long-term storage and the ribonucleolytic activity of the ribosomes in their embryos.

\section{MATERIAL AND METHODS}

These studies were done on winter rye grains of the Dańkowskie Zlote variety. The grain was harvested at the fully ripe stage, dried additionally in an airy room and stored in linen sacks in a hygrostat at a temperature of $18-20{ }^{\circ} \mathrm{C}$ and average air humidity of $50-55 \%$. In the study, grain harvested in the following years was used: 1976 (labeled further D), 1978 (C), and 1980 (B). In order to compare the results, rye grain of the same variety and optimum viability harvested in 1982 (A) was used.

Imbibition was carried out for $8 \mathrm{hrs}$ at a temperature of $+2 \mathrm{C}$ and the embryos isolated by hand. The ribosome fraction was isolated by the method of Golińska and Legocki (1973) with the following modifications: approx. 2-3 $\mathrm{g}$ of embryos were ground in a porcelain mortar with buffer "A" $-50 \mathrm{mM}$ Tris- $\mathrm{HCl}$, pH 7.8, $5 \mathrm{mM} \mathrm{MgCl}_{2}, 50 \mathrm{mM} \mathrm{KCl}, 2 \mathrm{mM} \mathrm{CaCl}$, $0.25 \mathrm{M}$ sucrose, $5 \mathrm{mM}$ mercaptoethanol. The homogenate was centrifuged at $21000 \times \mathrm{g}$ for $10 \mathrm{~min}$. The sediment was discerded and the supernatant centrifuged again under identical conditions. Triton X-100 $(10 \%)$ was added to the supernatant to a final concentration of $0.5 \%$ (Gumilevskaya et al. 1978) and centrifugation repeated at $21000 \times \mathrm{g}$ for $10 \mathrm{~min}$. The supernatant was layered over an $8 \mathrm{~cm}^{3}$ discontinuous sucrose concentration gradient prepared on buffer "A" $\left(4 \mathrm{~cm}^{3} 1 \mathrm{M}\right.$ sucrose and $4 \mathrm{~cm}^{3} 0.5 \mathrm{M}$ sucrose) and centrifuged for $5 \mathrm{hrs}$ at $135000 \times \mathrm{g}$. The ribosome pellet was delicately 
suspended in buffer "B" $(50 \mathrm{mM}$ Tris- $\mathrm{HCl}, \mathrm{pH} 7.8,50 \mathrm{mM} \mathrm{KCl}, 5 \mathrm{mM}$ $\mathrm{MgCl}_{2}, 5 \mathrm{mM}$ mercaptoethanol), after which it was layered over a discontinuous sucrose concentration gradient $\left(4 \mathrm{~cm}^{3} 0.5 \mathrm{M}\right.$ sucrose and $4 \mathrm{~cm}^{3}$ $0.25 \mathrm{M}$ sucrose prepared in buffer "B") and centrifuged for $3 \mathrm{hrs}$ at $135000 \times \mathrm{g}$. The ribosome pellet was again suspended in buffer "B" and centrifuged as before. The ribosomes used for determining ribonuclease activity were suspended in a small volume of buffer " $\mathrm{C}$ " $(10 \mathrm{mM}$ Tris- $\mathrm{HCl}$, pH 7.6, $100 \mathrm{mM} \mathrm{MgCl} 2,50 \mathrm{mM} \mathrm{KCl}$ ). The ribosome content of the suspension was determined, accepting that:

$$
\mathrm{E} \frac{1 \mathrm{~cm}, 1 \mathrm{mg} / \mathrm{cm}^{3}}{260 \mathrm{~nm}}=13.5 \text {. }
$$

The ribonucleolytic activity of ribosomes and postribosome supernatant was assayed using the method of Tuve and Anfinsen (1960) with slight modifications. A $0.05 \mathrm{~cm}^{3}$ sample of the studied RNase-containing solution was added to $2 \mathrm{~cm}^{3}$ of a $0.2 \%$ solution of highly polymerized yeast RNA in the appropriate buffer. The samples were incubated for $1 \mathrm{hr}$ at $37^{\circ} \mathrm{C}$. The reaction was halted by adding $0.5 \mathrm{~cm}^{3} 0.75^{\circ}$ uranyl acetate in $25 \%$ perchloric acid to the incubation medium. The samples were left for $15 \mathrm{~min}$ at a temperature of $0^{\circ} \mathrm{C}$, next protein and unhydrolysed RNA were removed by centrifugation for $10 \mathrm{~min}$ at $6000 \times \mathrm{g}$. Samples, $0.1 \mathrm{~cm}^{3}$ in volume, were removed from the supernatant, their volume adjusted to $3 \mathrm{~cm}^{3}$ and absorption at $260 \mathrm{~nm}$ was measured. The control contained RNA incubated without enzyme. After incubation, uranyl acetate was added, and only after that, the enzyme extract. A unit of ribonucleolytic activity (R.u) was taken to equal the amount of enzyme which, under the experimental conditions used, caused a change in absorption of 0.1 .

The following buffers were used to determine the optimum $\mathrm{pH}$ of the RNases linked with ribosomes:

$0.1 \mathrm{M}$ citrate-phosphate buffer, $\mathrm{pH}$ range 4.0-6.7;

$0.1 \mathrm{M}$ Tris- $\mathrm{HCl}, \mathrm{pH}$ range 7.4-8.6;

$0.2 \mathrm{M}$ Tris-maleic acid, $\mathrm{pH}$ range 6.8-7.3.

The conductivity of leachates was measured using a Redelkis type OK-102/1 conductometer. Protein was assayed using the method of Lowry et al. (1951) with purified trypsin as the standard.

The grain viability was determined after 7 days of germination at a temperature of $21 \mathrm{C}$ in Petri dishes, in the dark and in constant humidity.

\section{RESULTS AND DISCUSSION}

The rye grain used in this study came from four different years of harvest. At the time the study began, the viability of the grain was decidedly 
differentiated (Table 1). Clear loss of viability was observed as the storage time increased. An additional indication of the degree of viability loss could be the conductivity of the leachates presented on Fig. 1. No clear-cut relationship between grain viability and exudate conductivity was observed, however.

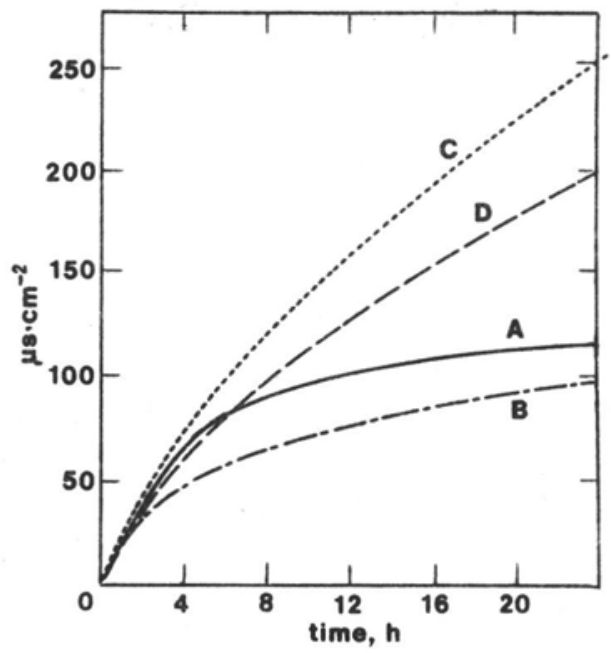

Fig. 1. Changes in conductivity during imbibition of rye seeds of different ages. A - grain harvested in 1982, B - grain harvested in 1980, C - grain harvested in 1978, D grain harvested in 1976

The absolute and specific ribonucleolytic activities of rye embryo ribosomes and the post-ribosome supernatant are given in Table 1. As can be seen from the data presented there, the highest ribonucleolytic activity was characteristic of ribosomes from embryos in rye grains having the greatest viability. The fall in the germination ability of grain caused by long-term storage was accompanied by a decrease in the activity of RNases associated with ribosomes. It should be noted, however, that in the grain with the lowest viability (D), the specific activity was still $57 \%$ that of the RNases associated with the ribosomes from the control grains, Similar relationships were found studying the activity of RNases in the $135000 \times \mathrm{g}$ supernatant (Table 1). In this case, however, the supernatant obtained from the grain harvested in 1978 was characterized by a higher activity than the supernatant from the grain harvested two years earlier.

In spite of the fact that distinct differences were found in the ribonucleolytic activities of ribosomes from embryos of rye grains of different viability, a closer interpretation of this phenomenon is difficult. This results from the fact that the structure of the ribosome of higher plants and of the 
Table 1

Ribonucleolytic activity associated with rye germ ribosomal (and supernatant $135000 \times \mathrm{g}$ ) preparations

\begin{tabular}{|l|c|c|c|c|c|}
\hline \multirow{2}{*}{$\begin{array}{c}\text { Sample } \\
\text { of grain }\end{array}$} & \multirow{2}{*}{$\begin{array}{c}\text { Germinat- } \\
\text { ion ability }\end{array}$} & \multicolumn{4}{|c|}{ Ribonucleolytic activity } \\
\cline { 3 - 6 } & & $\begin{array}{c}\text { specific activity, } \\
\text { R.u. per mg of } \\
\text { ribosomes }\end{array}$ & $\begin{array}{c}\text { total activity, } \\
\text { R.u. per 100 } \\
\text { embryos }\end{array}$ & $\begin{array}{c}\text { specific activity, } \\
\text { R.u. per mg of } \\
\text { protein }\end{array}$ & $\begin{array}{c}\text { total activity, } \\
\text { R.u. per 100 } \\
\text { embryos }\end{array}$ \\
\hline A & 92 & 1517 & 1573 & 31.29 & 8104 \\
B & 51 & 1363 & 929 & 18.50 & 4014 \\
C & 24 & 1075 & 782 & 24.90 & 4332 \\
D & 2 & 877 & 707 & 20.69 & 3517 \\
LSD P $=1 \%$ & 4.6 & 121 & 126 & 2.34 & 388 \\
\hline
\end{tabular}

A grain harvested in 1982. B in 1980. C in 1978. D in 1976.

function of its components are still not understood well. Nevertheless. it is known that a small fraction of ribosomes found in non-viable seeds retains its ability to participate in the process of translation (Anderson 1977. Zalewski 1982). On the other hand, different studies have shown that the ribosomes found in aged seeds have a smaller mass (Roberts and Osborne 1973), a lower ribosome protein content (Zalewski and Weidner 1982) and also, an altered $18 \mathrm{~S}$ and $25 \mathrm{~S}$ rRNA structure (Roberts and Osborne 1973, Bray and Chow 1976a, b, Weidner et al. 1984).

As results from the data presented in this paper, (Table 1, Fig. 2) the changes which the ribosomes undergo during long-term storage, also concern their ribonucleolytic activity. It should be, however, stated that the RNase activity associated with ribosomes still remains high, even in grain with low viability. This also applied to the ribonucleases found in the post-ribosomal supernatant. The finding of ribonucleolytic activity in a wide $\mathrm{pH}$ range (from $\mathrm{pH} 4.2$ to 8.3 ) points to the heterogeneity of the RNases associated with rye grain embryo ribosomes.

In all of the analysed samples, the greatest ribonucleolytic activity of ribosomes was found between $\mathrm{pH}$ 6.8-6.9. Additionally, a rather small activity peak was observed in the $\mathrm{pH}$ range 4.4-6.6. Only in the grain with the lowest viability were two distinct additional activity peaks found at $\mathrm{pH} 5.0$ and 8.3 (Fig. 2). This points to a certain loosening of the ribosome structure in the oldest grain. The appearance of two additional high ribosomal RNase activities in this grain can be explained in this way. Siwecka et al. (1979) have found that there exists a ribonucleolytic activity tightly associated with the interior of the ribosome which is independent of the ribonucleolytic activity connected with the surface of the ribosome. 


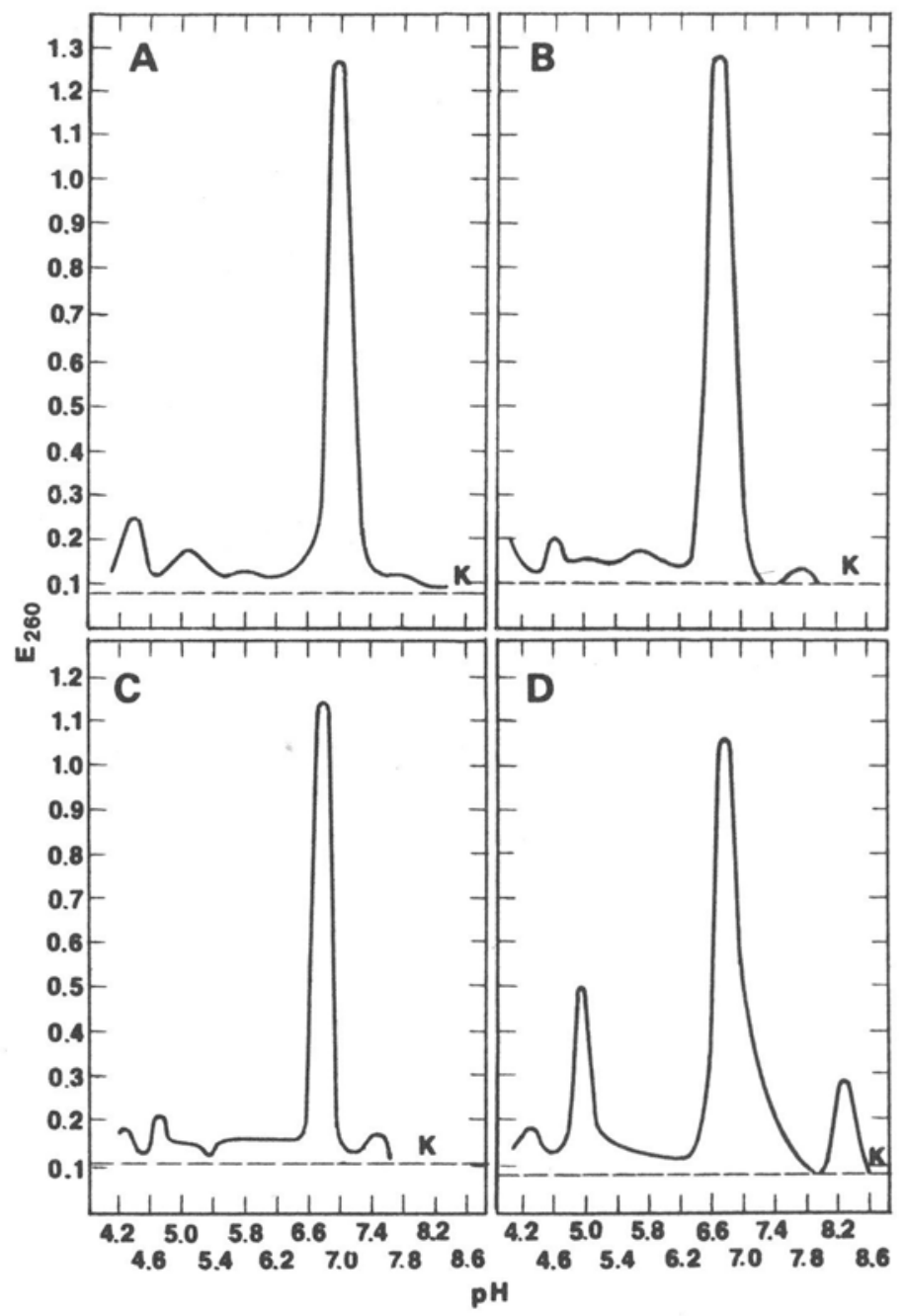

Fig. 2. The effect of $\mathrm{pH}$ on the ribonucleolytic activity associated with rye germ ribosomes. $0.1 \mathrm{M}$ citrate-phosphate buffer was used for $\mathrm{pH} 4.0-6.7 ; 0.2 \mathrm{M}$ Tris-maleic acid for $\mathrm{pH}$ 6.8-7.3 and $0.1 \mathrm{M}$ Tris- $\mathrm{HCl}$ for $\mathrm{pH}$ 7.4-8.6. $\mathrm{K}$ - level of control sample. A - grain harvested in 1982. B in 1980. C - in 1978, D - in 1976

Acknowledgments

This study was supported by IHAR under the proiect PW-09.1-B/01-05.

\section{REFERENCES}

Anderson J. D.. 1977. Adenylate metabolism of embryonic axes from deteriorated soybean seeds. Plant Physiol. 59: 610-614. 
Barker G. R.. Douglas T.. 1960. The function of ribonuclease in germinating peas. Nature 118: 943-944.

Bray C. M.. Chow T.-Y.. 1976a. Lesions in post-ribosomal supernatant fractions associated with loss of viability in pea (Pisum arvense) seed. Biochim. Biophys. Acta 442: $1-13$.

Bray C.M., Chow T.-Y., 1976b. Lesions in the ribosomes of nonviable pea (Pisum arvense) embryonic axis tissue. Biochim. Biophys. Acta 442: 14-22.

Golińska B.. Legocki A. B.. 1973. Purification and some properties of elongation factor 1 from wheat germ. Biochim. Biophys. Acta 324: 156-170.

Gołaszewski T., 1964. Badania nad rybonukleazami roślin. Post. Bioch. 10: 369-379.

Gumilevskaya N. A.. Alekhina S. K.. Chumikina L. V., Kretovich W. L., 1978. Pea seed ribosomal proteins behaving as anions at pH 7.8. Fizyol. Rast. 43: 678-686.

Hsiao T.C.. 1968. Ribonuclease activity associated with ribosomes of Zea mays. Plant Physiol. 43: 1355-1361.

Kulka K., 1969. Aktywność ATPazy i RNazy w zarodkach ziarna jęczmienia jarego w okresie spoczynku pożniwnego. Acta Soc. Bot. Pol. 38: 247-254.

Kulka K.. 1971. Biochemiczne aspekty starzenia się ziarna owsa i ięczmienia. Zesz. Nauk. WSR Olsztyn. No 6.

Lowry O. H., Rosebrough N. J., Farr A. L. Randall R. J., 1951. Protein measurment with the Folin phenol reagent. J. Biol. Chem. 193: 265-275.

Roberts E. H., Osborne J. D., 1973. Protein synthesis and viability in rye grains. In: Seed ecology. W. Heydecker (ed.). Butterworths, London. pp. 99-114.

Rytel M., Szarkowski J. W.. Gołaszewski T., 1968. Some features of mitochondrial ribonucleic acid from rye leaves. Acta Soc. Bot. Pol. 38: 25-33.

Sierakowska H., 1969. Rozmieszczenie specyficznych nukleaz i ich rola w metabolizmie kwasów nukleinowych. Post. Bioch. 15: 193-217.

Siwecka M. A., Rytel M., Szarkowski J. W., 1979. The presence of deoxyribonucleolytic activity in cytoplasmic ribosomes of rye (Secale cereale L.) germs. Acta Biochim. Polon. 26: 97-102.

Szafrański P.. Perzyński S., Krasicka B., 1964. Decomposition of ribonucleic acid from the liver microsomal fraction. Acta Biochim. Polon. 11: 159-168.

Szarkowski J.W., 1965. Badania porównawcze nad kwasami rybonukleinowymi i rybonukleazami zielonych i etiolowanych roślin wyższych. PWN, Warszawa.

Tal M.. Elson D., 1963. The location of ribonuclease in E. coli. Biochim. Biophys. Acta $76: 40-51$.

Tuve T. W.. Anfinsen C. B.. 1960. Preparation and properties of spinach ribonuclease. J. Biol. Chem. 235: 3437-3441.

Weidner S., Zalewski K., Rejowski A., 1984. Effect of low contents of stored RNA in embryos of unripe and aged wheat grains on total metabolism of ribonucleic acid during germination. IV Congres of FESPP (Strasbourg-France).

Zalewski K., 1982. Formowanie polirybosomów w zarodkach kiełkującego ziarna pszenicy o różnej żywotności. Hod. Rośl. Aklim. 26: 1-9.

Zalewski K., Weidner S.. 1982. Changes in ribosomal proteins of wheat embryos during accelerated ageing of the grain. Acta Soc. Bot. Pol. 51: 301-308. 
Metabolizm starych nasion. Aktywność rybonukleolityczna rybosomów zarodków ziarna żyta $w$ różnym wieku

Streszczenie

Badania przeprowadzono na ziarniakach żyta ozimego, pochodzących z różnych lat zbioru, o wyraźnie zróżnicowanej żywotności. Stwierdzono większą sumaryczną aktywność rybonukleolityczną supernatantu powstałego po odwirowaniu rybosomów niż samych rybosomów. W miarę utraty przez ziarno żyta zdolności do kiełkowania, aktywność rybonukleaz związanych z rybosomami cytoplazmatycznymi zmniejszała się. Podobny związek między aktywnością RNaz i żywotnością ziarna zauważono badając supernatant postrybosomowy. W ziarnie o najmniejszej żytwotności $(2 \%$ ), w porównaniu $\mathrm{z}$ ziarnem $\mathrm{w}$ pełni żywotnym, zaobserwowano dwa dodatkowe szczyty aktywności RNaz związanych z rybosomami (pH 5,0 i 8,3). 